\title{
RESPON WISATAWAN TERHADAP PENGEMBANGAN BATUR GLOBAL GEOPARK BALI
}

\author{
I Gede Gian Saputra \\ Email: giansukses78@gmail.com
}

\begin{abstract}
Batur Global Geopark is one of the new tourism attractions being developed by the government in Kintamani, Bali. This new attraction has not contributed significant impacts to the number of tourists visiting Kintamani. Lack of site managemenet and promotion are among the causes. This study analyzes the response of tourists towards the development of Batur Global Geopark based on attitudes, perceptions, and participation. Data collected by observation, in-depth interviews, surveys, and analyzed using Likert scale by giving score against to the response. The study shows that the development of Kintamani geopark is expected to be one of the tourism products which could provide a new attraction for tourist to come to Kintamani. Accordingly, the government needs more in-depth introduction of Batur Global Geopark by creating special tour itinerary to attaind the purpose of conservation, education, and geotourism.
\end{abstract}

Keywords: tourists response, Batur Global Geopark, development, Kintamani

\section{Pendahuluan}

Dalam upaya melestarikan warisan geologi dan sekaligus memperoleh manfaat yang berkelanjutan bagi kesejahteraan masyarakat lokal, konsep pembangunan melalui pengembangan taman bumi atau geopark kini menjadi pilihan yang menarik di Indonesia. Perkembangan geopark diawali dengan terbentuknya suatu organisasi non-pemerintahan yang bertujuan melindungi warisan geologi di negara-negara Eropa bernama European Geopark Network (EGN) pada tahun 2001. Selanjutnya UNESCO memfasilitasi dan membentuk organisasi yang mampu menampung lebih banyak lagi negara-negara anggota sehingga terbentuklah Global Geopark Network (GGN) pada tahun 2004.

Berdasarkan pedoman GGN UNESCO (2004), tujuan geopark adalah menggali, mengembangkan, menghargai, dan mengambil manfaat dari hubungan erat antara warisan geologi dan segi lainnya dari warisan alam 
yang berupa budaya, dan nilai-nilai di area tersebut. Untuk mencapai tujuannya, sebuah geopark memiliki batas-batas yang ditetapkan dengan jelas dan memiliki kawasan yang cukup luas untuk pembangunan ekonomi lokal.

Di dalam geopark, terdapat tiga kegiatan penting yaitu konservasi, pendidikan, dan geowisata. Sebelum diakui oleh UNESCO menjadi anggota jaringan geopark dunia (GGN), sebuah daerah dapat diusulkan untuk ditetapkan menjadi geopark nasional di negaranya. Misalnya, China memiliki sekitar 129 geopark nasional dengan 27 di antaranya merupakan geopark anggota GGN.

Indonesia dengan luas wilayah hampir sama dengan China dan memiliki keragaman geologi sangat berpotensi untuk memiliki banyak geopark, baik geopark nasional maupun geopark internasional. Jumlah geopark yang diakui UNESCO atau geopark anggota GGN di seluruh dunia saat ini ada 90 kawasan. Di kawasan Asia Tenggara, geopark hanya dimiliki oleh Malaysia, Vietnam dan Indonesia, masing- masing satu. Geopark yang dimiliki Indonesia adalah kawasan Kaldera Gunung Batur di Kintamani, Kabupaten Bangli, Provinsi Bali. Awal pengusulan adalah tahun 2008, penetapannya tahun 2012. Dengan hadirnya Batur Global Geopark, bertambahlah daya tarik wisata Bali, memperkaya daya tarik wisata budaya dan wisata bahari (Putra 2014)

Sejak kawasan Kintamani resmi masuk GGN, mulailah nama Batur Global Geopark dipopulerkan oleh pemerintah. Batur Global Geopark berhasil masuk menjadi anggota GGN, karena kawasan Batur Kintamani memiliki potensi dan peluang yang tinggi untuk pengembangannya. Keindahan Kaldera Batur didukung oleh beberapa tempat atau spot yang strategis sehingga memungkinkan untuk melihat seluruh keindahan kaldera, gunung, danau, hamparan warisan geologi, dan desa-desa tradisional beserta keragaman budaya serta hayatinya (Foto 1).

Pengembangan Kawasan Batur Global Geopark juga memberikan daya tarik wisata yang lebih beragam kepada wisatawan di Bali, karena tercipta alternatif wisata yang belum pernah dikembangkan. Wisatawan dapat menikmati keindahan dan sekaligus mendapatkan pengetahuan betapa pentingnya kelestarian alam dari perjalanan wisata di Batur Global Geopark. Kintamani yang telah dikembangkan sebagai destinasi pariwisata yang ditambah dengan branding Batur Global Geopark diharapkan akan mampu meningkatkan kunjungan wisatawan baik dari kuantitas ataupun kualitas. Namun, bila dilihat dari data pertumbuhan kunjungan wisatawan ke Kintamani, wisatawan terlihat mulai meninggalkan Kintamani sebagai destinasi wisatanya. Bukti permasalahan ini dapat terlihat padal Tabel 1 tentang kunjungan wisatawan ke Kintamani selama 5 tahun terakhir. 


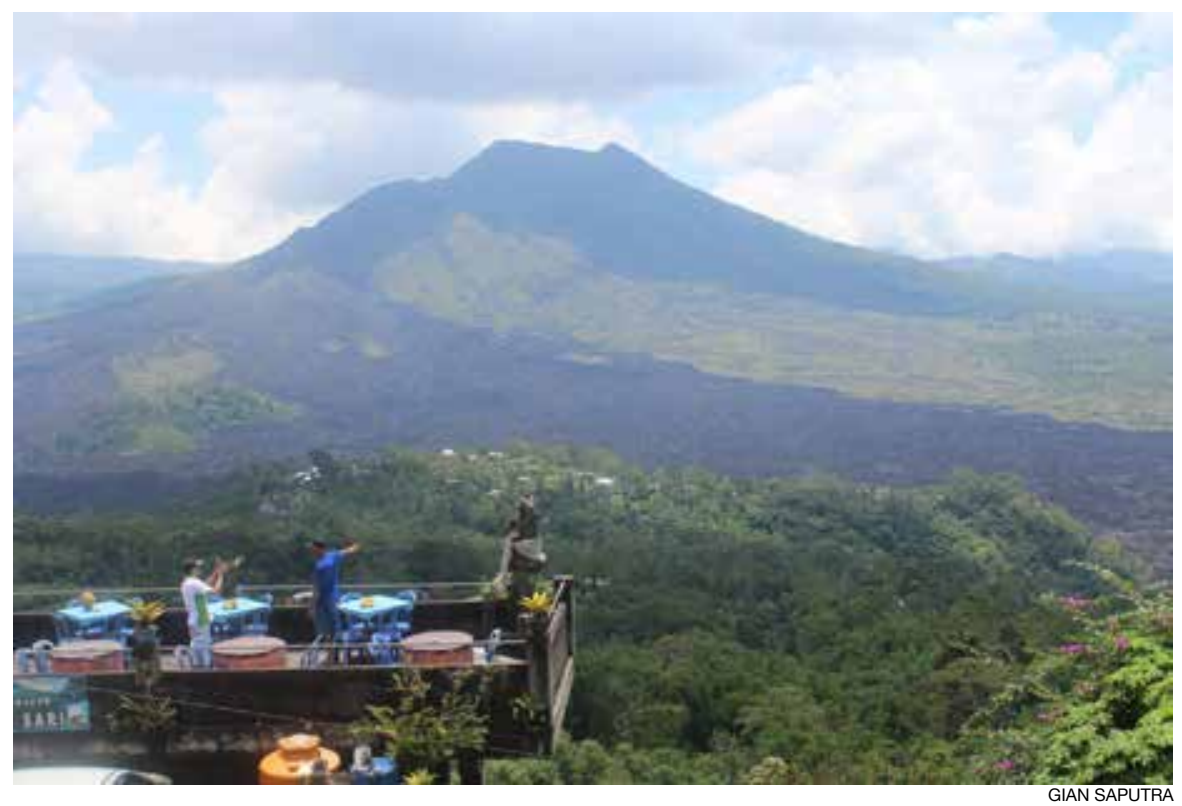

Foto 1. Pemandangan alam Kintamani, dengan pesona Gunung Batur yang indah, dan lembah yang menjadi area Geopark

Tabel 1 Perbandingan Jumlah Kunjungan Wisatawan ke Kintamani dan Bali 2010-2014

\begin{tabular}{cccccc}
\hline No. & Tahun & $\begin{array}{c}\text { Kunjungan ke } \\
\text { Kintamani }\end{array}$ & $\begin{array}{c}\text { Pertumbuhan } \\
(\%)\end{array}$ & $\begin{array}{c}\text { Kunjungan ke } \\
\text { Bali }\end{array}$ & $\begin{array}{c}\text { Pertumbuhan } \\
(\%)\end{array}$ \\
\hline 1. & 2010 & 375.789 & - & 7.124 .749 & - \\
2. & 2011 & 495.710 & 31 & 8.240 .100 & 15 \\
3. & 2012 & 502.805 & 1 & 10.159 .261 & 23 \\
4. & 2013 & 564.451 & 12 & 10.332 .670 & 1 \\
5. & 2014 & 566.352 & 3 & 11.687 .467 & 13 \\
& & 501.021 & Rata-rata 11 & 9.508 .849 & Rata-rata 13 \\
\hline
\end{tabular}

Sumber: Dinas Pariwisata Provinsi Bali Tahun 2015

Tabel 1 menunjukkan angka kunjungan wisatawan dalam lima tahun terakhir ke destinasi pariwisata Kintamani dari tahun ke tahun mengalami peningkatan. Dari segi kuantitas pariwisata Kintamani mengalami peningkatan. Namun, apabila dibandingkan dengan pertumbuhan pariwisata di Bali, Kintamani sangat jauh ketinggalan. Hal ini berarti, Kintamani sebagai satu-satunya geopark yang ada di Indonesia dan telah masuk jaringan GGN belum berhasil menjadikan Kintamani sebagai destinasi yang berkualitas yang menjadi pilihan wisatawan.

Dalam mengatasi permasalahan ini, perlu diketahui bagaimana sebenarnya respon dari wisatawan yang berkunjung ke Kintamani. Respon wisatawan penting diketahui untuk melihat apakah pengembangan geopark 
di Kintamani diminati dan mendapatkan dukungan positif atau sebaliknya. Oleh karena itu, kajian tentang wisatawan dalam pengembangan geopark masih sangat diperlukan dalam mendukung upaya pemerintah meningkatkan daya tarik wisatawan ke Kintamani. Selama ini, kajian yang terkait geopark masih sangat minim jika dibandingkan dengan kajian pariwisata yang bersifat umum. Apalagi, geopark tergolong suatu konsep yang baru dalam industri kepariwisataan.

\section{Respon Wisatawan}

Respon merupakan balasan atau tanggapan seseorang terhadap sesuatu. Proses merespon dilatarbelakangi oleh tiga hal yakni sikap, persepsi dan partisipasi. Respon juga dapat memulai atau membimbing tingkah laku individu yang bersangkutan karena tanggapan yang dihasilkan merupakan pengaruh dari lingkungan tersebut (Swastha dan Handoko, 1997). Dalam berkomunikasi dengan dunia luar, orang menggunakan kelima indranya untuk menerima tanda-tanda dan pesan-pesan. Cara orang menerima dengan indra dan respons yang ditimbulkan berbeda-beda karena respons (persepsi, sikap, dan perilaku) seseorang dibentuk oleh budaya (Eilers, 1995).

Dalam konteks memahami respon wisatawan, akan dijelaskan siapa wisatawan itu. Pemerintah mengeluarkan UU No. 10 tahun 2009 yang menyatakan wisatawan adalah "orang yang melakukan wisata". Wisatawan sering disebut sebagai orang yang bepergian dari tempat tinggalnya untuk berkunjung ke tempat lain dengan menikmati perjalanan dari kunjungannya itu (Spillane, 1993). Organisasi pariwisata dunia juga memberikan suatu definisi terkait wisatawan. Wisatawan merupakan orang atau sekelompok orang yang melakukan perjalanan untuk rekreasi atau liburan. Seorang wisatawan melakukan perjalanan paling tidak sejauh $80 \mathrm{~km}$ (50 mil) dari rumahnya dengan tujuan rekreasi (UNWTO, 2011). Berdasarkan berbagai pengertian wisatawan itu, dapat ditarik kesimpulan bahwa pengertian mengenai wisatawan berisi beberapa hal, di antaranya: pertama tempat tinggal asal wisatawan dan lokasi tujuan wisata, kedua jangka waktu dan jarak perjalanan, ketiga tujuan dan kepentingan melakukan perjalanan (Pitana, 2005).

Dalam konteks sosiologis, perubahan persepsi serta motivasi wisatawan dalam melakukan perjalanan wisata terus menerus mengalami perubahan. Menurut Plog (dalam Pitana, 2005), wisatawan dapat dikelompokkan berdasarkan tipologi wisatawan yaitu allocentris (wisatawan hanya ingin mengunjungi tempat-tempat yang belum diketahui, bersifat petualangan, dan mau memanfaatkan fasilitas yang disediakan oleh masyarakat lokal); psychocentris (wisatawan yang hanya ingin mengunjungi daerah tujuan wisata sudah mempunyai fasilitas yang sama dengan di negaranya); mid- 
centris (wisatawan terletak di antara tipologi allocentris dan psychocentris).

Menurut Pitana (2005), tipologi wisatawan perlu diketahui untuk tujuan perencanaan, termasuk dalam pengembangan kepariwisataan. Tipologi yang lebih sesuai adalah tipologi berdasarkan atas kebutuhan riil wisatawan, sehingga pengelola dalam melakukan pengembangan daya tarik wisata sesuai dengan segmentasi wisatawan. Dalam penelitian ini, wisatawan yang dimaksud adalah orang/ sekelompok orang yang melakukan perjalanan dengan tujuan utama untuk liburan baik dari dalam negeri (domestik) ataupun asing (mancanegara) dan berkunjung/ menginap di kawasan Batur Global Geopark. Respon wisatawan yang dimaksud adalah sikap, persepsi, dan partisipasi wisatawan baik positif maupun negatif yang muncul karena adanya rangsangan berupa interaksi yang terbentuk pada kawasan Batur Global Geopark.

\section{Teori Siklus Hidup Area Pariwisata}

Setiap produk atau destinasi wisata memiliki siklus hidup sendiri-sendiri. Menurut Butler (2006) terdapat beberapa fase pengembangan pariwisata (siklus hidup area pariwisata) yang membawa implikasi serta dampak yang berbeda, diantaranya :

Eksplorasi atau penemuan (exploration), pada tahap ini destinasi masih relatif belum terjamah dan baru dikenal beberapa wisatawan, sehingga belum tersedia fasilitas pariwisata apapun. Pada tahap ini terjadi kontak yang tinggi antara wisatawan dengan masyarakat lokal, karena wisatawan menggunakan fasilitas lokal yang tersedia. Karena jumlah yang terbatas dan frekuensi yang jarang, maka dampak sosial budaya ekonomi pada tahap ini masih sangat kecil.

Keterlibatan (involvement), pada tahapan ini merupakan tahap pelibatan masyarakat terhadap situasi yang berkemang di daerah mereka. Dengan meningkatnya jumlah kunjungan, maka sebagaian masyarakat lokal mulai menyediakan berbagai fasilitas yang memang diperuntukan bagi wisatawan. Kontak antara wisatawan dengan masyarakat masih tinggi dan masyarakat mulai mengubah pola-pola sosial yang ada untuk merespon perubahan ekonomi yang terjadi. Di sinilah mulainya suatu daerah menjadi suatu destinasi wisata, yang ditandai oleh mulai adanya promosi.

Pembangunan (development), investasi dari luar mulai masuk, serta mulai munculnya pasar wisata secara sistematis. Daerah semakin terbuka secara fisik, dan promosi semakin intensif, fasilitas lokal sudah tersisih atau digantikan oleh fasilitas yang benar-benar berstandar internasional, dan atraksi buatan sudah mulai dikembangkan, menambahkan atraksi yang asli alami. Berbagai barang dan jasa impor termasuk tenaga kerja asing, untuk mendukung perkembangan pariwisata yang pesat.

Konsolidasi (consolidation), pariwisata sudah dominan dalam struktur 
ekonomi daerah, dan didominasi ekonomi ini dipegang oleh jaringan internasional atau major chains and franchise. Jumlah kunjungan wisatawan masih naik, tetapi pada tingkat yang lebih rendah. Pemasaran semakin gencar dan diperluas untuk mengisi fasilitas yang sudah dibangun. Fasilitas lama sudah mulai ditinggalkan.

Stagnan (stagnation), kapasitas berbagai faktor sudah terlampaui diatas daya dukung (carying capacity), sehingga menimbulkan masalah ekonomi, sosial dan lingkungan. Kalangan industri sudah mulai bekerja keras untuk memenuhi kapasitas dari fasilitas yang dimiliki, khususnya dengan mengharapkan repeater guest dan wisata konvensi/ bisnis. Pada fase ini, atraksi buatan sudah mendominasi atraksi asli alami (baik budaya ataupun alam), citra awal sudah mulai luntur, dan destinasi sudah tidak lagi populer.

Penurunan (decline), wisatawan sudah mulai beralih ke destinasi wisata baru atau pesaing, dan yang ditinggal hanya "sisa-sisa", khususnya wisatawan yang hanya berakhir pekan. Banyak fasilitas pariwisata sudah beralih atau dialihkan fungsinya untuk kegiatan non-pariwisata, sehingga destinasi semakin tidak menarik bagi wisatawan. Partisipasi lokal mungkin meningkat lagi, terkait dengan harga yang merosot turun dengan melemahnya pasar. Destinasi bisa saja berkembang menjadi destinasi kelas rendah atau secara total kehilangan jati diri sebagai destinasi wisata.

Peremajaan (rejuvenation), perubahan secara dramatis bisa terjadi (sebagai hasil dari berbagai usaha berbagai pihak, menuju perbaikan atau peremajaan. Peremajaan ini bisa terjadi karena inovasi dan pengembangan produk baru, atau menggali atau memanfaatkan sumber daya alam dan budaya yang sebenarnya.

Dalam penelitian ini, teori siklus hidup area wisata akan membantu memperjelas posisi perkembangan Kintamani dalam industri kepariwisataan di Bali. Dilihat dari beberapa indikator perkembangan pariwisata Kintamani telah mencapai pada fase stagnasi (stagnation), yaitu kapasitas berbagai faktor sudah terlampaui diatas daya dukung (carring capacity) sehingga masalah ekonomi, sosial dan lingkungan ataupun budaya sering terjadi. Kalangan industri sudah mulai bekerja keras untuk memenuhi kapasitas dari fasilitas yang dimiliki, khususnya dengan mengharapkan repeater guest dan wisata konvensi/ bisnis. Sebagai contoh, rerstoran yang ada Kintamani melakukan kerjasama dengan biro perjalanan wisata dengan memberikan potongan harga jika membawakan tamu. Pada fase ini, atraksi buatan sudah mendominasi atraksi asli alami (baik budaya ataupun alam), citra awal sudah mulai luntur, dan destinasi sudah tidak lagi populer. Pada kasus ini Kintamani dikunjungi karena ada kerja sama restoran dan biro perjalanan wisata bukan karena keindahan danau dan Gunung Batur sebagai faktor penarik yang utama (Foto 2). 


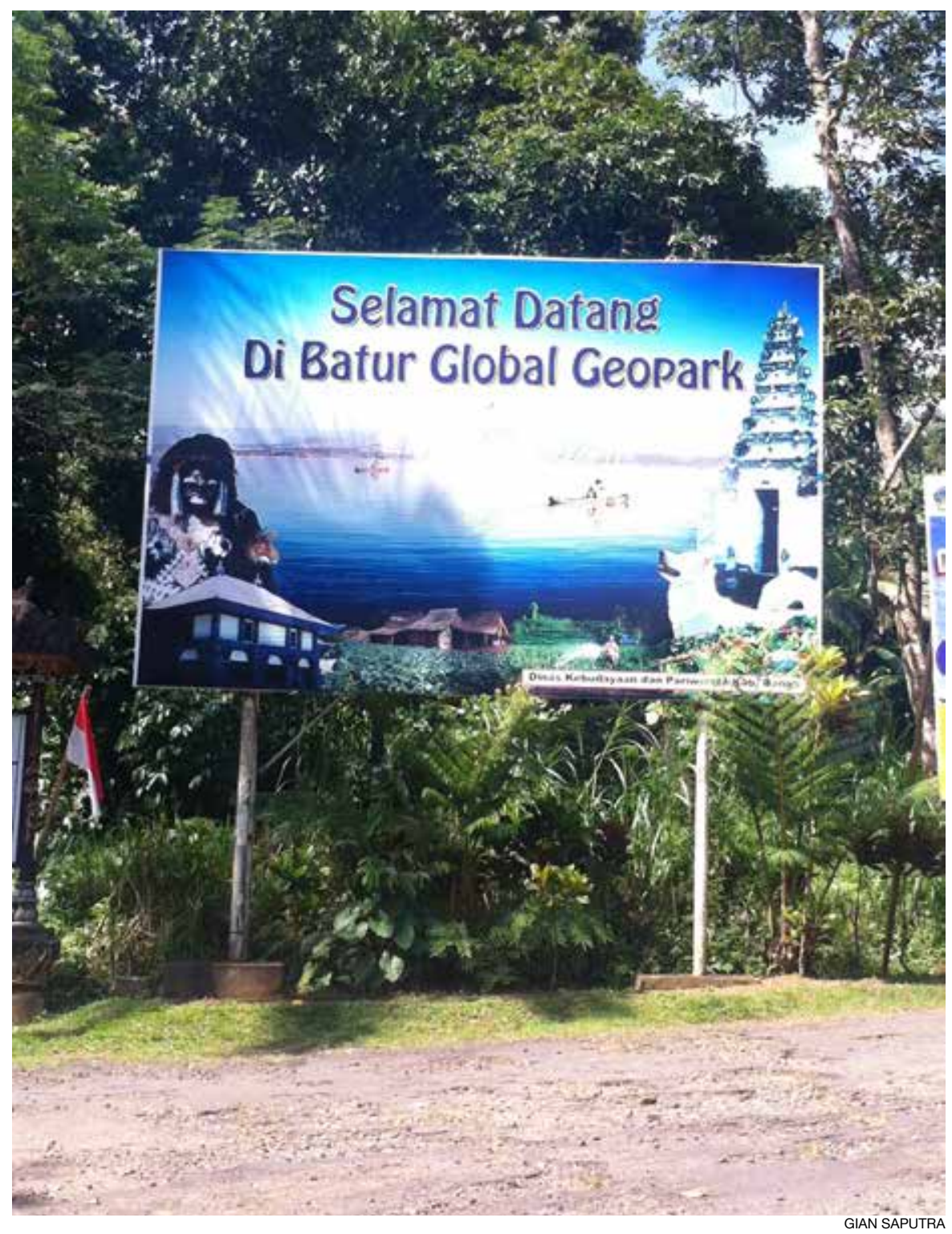

Foto 2. Tanda daya tarik wisata Batur Global Geopark.

\section{Karakteristik Wisatawan}

Data yang diperoleh dalam penelitian ini dilakukan dengan metode survei dengan menyebarkan 100 kuisoner kepada wisatawan yang sedang berkunjung ke kawasan Batur Global Geopark baik mancanegara maupun domestik. Penyebaran ini dilakukan selama tiga bulan yang dimulai pada bulan April hingga Mei 2015. Berikut gambaran karakteristik wisatawan yang menjadi responden dalam penelitian. 


\subsection{Berdasarkan Jenis Kelamin}

Wisatawan yang berjenis kelamin laki-laki berjumlah $51 \%$ dan perempuan berjumlah 49\%.Untuk melakukan aktivitas wisata memang seseorang harus banyak mengeluarkan waktu.Melihat hal tersebut memang pantas seorang pria lebih mudah untuk melakukan perjalanan. Di sisi lain, seorang perempuan memang lebih banyak memerlukan waktu untuk mempertimbangkan keputusannya. Terlihat sekali perbedaan antara seorang pria dan perempuan, di mana pria tidak terlalu banyak berpikir akan bagaimana jadinya pada saat berwisata namun seorang perempuan biasanya lebih terencana, semua aktivitasnya harus direncanakan secara detil. Seorang pria bisa sudah berkunjung dua kali, seorang perempuan bisa baru berkunjung hanya sekali ke suatu daya tarik wisata.

\subsection{Berdasarkan Umur}

Mayoritas wisatawan yang berkunjung ke Batur Global Geopark merupakan wisatawan yang berumur diantara 22 sampai 35 tahun. Dari survei ini, wisatawan diklasifikasi menjadi 5 kelompok umur yaitu dibawah 21 tahun, 22 sampai 35 tahun, 36 - 5o tahun, dan 65 keatas. Sebanyak 43\% merupakan wisatawan yang berumur 22 - 35 tahun. Ini berarti wisatawan yang berkunjung ke Batur Global Geopark relatif cukup muda, berarti Batur Global Geopark merupakan daya tarik wisata bagi kaum muda. Antara wisatawan domestik dan mancanegara memiliki persamaan jika dilihat dari umur wisatawan yaitu relatif cukup muda. Wisatawan berusia muda, selain memiliki uang yang cukup, mereka juga masih kuat secara fisik sehingga kuat melakukan perjalanan dan siap untuk melakukan aktivitas wisata bahkan yang menantang sekali pun, seperti mendaki di Gunung Batur ataupun sekedar bersepeda.

\subsection{Berdasarkan Pekerjaan}

Untuk jenis pekerjaan wisatawan yang berkunjung ke Batur Global Geopark sangat bervariasi, mereka terdiri dari pekerja di bagian manajemen, pemerintahan, penjualan, jasa, ibu rumah tangga, administratif, pensiunan, konstruksi, pelajar/ mahasiswa, wiraswasta, pekerja professional. Sebanyak $27 \%$ adalah wisatawan yang bekerja sebagai wirausaha. Sesuai dengan hasil survei yang berdasarkan umur menjelaskan bahwa, Batur Global Geopark banyak dikunjungi wisatawan yang berumur relatif muda, sehingga tepat apabila Batur Global Geopark banyak dikunjungi wisatawan yang pekerjaannya wirausaha.

Batur Global Geopark memang berbeda dari daerah lainnya, terlihat dari wisatawan yaitu wirausaha yang berumur muda. Kelas wisatawan yang menginap di Batur Global Geopark jelas merupakan wisatawan yang memiliki ketertarikan terhadap alam dan lingkungan. Dari hasil survei ini 
memperlihatkan bahwa wisatawan didominasi oleh wirausaha.Ini artinya wisatawan yang berkunjung memang wisatawan yang memiliki usaha sendiri. Melihat tipikal wisatawan seperti ini, biasanya wisatawan tersebut akan mudah untuk melihat peluang usaha yang ada.

\section{4 Berdasarkan Tingkat Pendidikan}

Level pendidikan wisatawan diklasifikasi menjadi 5 kelompok, yaitu elementary school, high school/ vocational school, 2 year college, 4 year college, master degree, dan doctorate degree. Hasil yang diperoleh adalah elementary school $\mathrm{0} \%$, high school/ vocational school 10\%, 2 year college $15 \%$, 4 year college 20\%, master degree 50\%, dan doctorate degree $5 \%$. Ini berarti wisatawan memiliki level pendidikan yang cukup tinggi sebagai wisatawan. Di sini juga terlihat dari segmen pasar wisatawan di Batur Global Geopark membuktikan bahwa 50 \% wisatawan yang berkunjung ke Batur Global Geopark adalah wisatawan yang mempunyai level pendidikan master degree.

Hasil survei memberikan penjelasan, bagaimana Batur Global Geopark bisa diminati oleh wisatawan. Apabila diingat kembali, wisatawan yang berkunjung adalah wisatawan yang berumur relatif muda dan sekarang memiliki pendidikan yang relatif tinggi.Ini jelas membuktikan bahwa pangsa pasar dari Batur Global Geopark adalah pangsa pasar yang berkelas dan memiliki nilai lebih dari pangsa pasar DTW lainnya di Kabupaten Bangli. Nilai lebih tersebut adalah alam dan budaya masyarakat di kawasan Batur Global Geopark yang tidak terdapat pada daerah lainnya. Itulah yang menyebabkan wisatawan ingin untuk berkunjung ke Batur Global Geopark. Berbeda dengan daerah lain di Bali, Batur Global Geopark tidak jarang dijadikan tempat untuk melakukan suatu penelitian bagi pelajar atau pun wisatawan. Melihat wisatawan yang berkunjung memiliki pengetahuan yang relatif tinggi, jelas akan mempengaruhi citra Batur Global Geopark dimata internasional. Salah satu bukti yang bisa dilihat adalah kawasan ini memiliki dua branding internasional, yaitu global geopark dan world cultural heritage.

\subsection{Berdasarkan Tempat Menginap}

Sebagaian besar wisatawan yang berkunjung ke Kintamani menginap di area Kuta, Sanur, Ubud, Nusa Dua dan hanya 20\% yang menginap di Kintamani. Hal ini dikarenakan Kintamani memang bukanlah dijadikan tempat menginap yang diatur dalam tata ruang provinsi Bali. Kintamani menjadi destinasi pariwisata, sehingga apabila ada wisatawan yang ingin menginap, wisatawan tersebut tentu memiliki minat khusus. Hal ini adalah suatu tantangan bagi Kintamani yang telah memiliki branding Batur Global Geopark agar semakin menjadi destinasi yang lebih berkualitas dengan 
pariwisata minat khusus. Pariwisata minat khusus merupakan produk unggulan untuk menjaga eksisitensi Kintamani ditengah banyaknya muncul destinasi baru. Apabila dibiarkan begitu saja, akan sulit bagi Kintamani mendapat keuntungan yang tujuannya untuk mensejahterakan masyarakat lokal.

\subsection{Berdasarkan Orang yang Diajak Berwisata}

Dilihat dari perjalanannya, untuk wisatawan yang ke Batur Global Geopark cenderung melakukan perjalanan dengan temannya. Hasil survey ini memberitahukan 55\% wisatawan melakukan perjalanan dengan teman, 25\% sendirian, 15\% dengan pasangan dan 5\% dengan keluarganya. Dari kondisi ini, terlihat wisatawan yang baru pertama kali berkunjung adalah tahap membandingkan dan tahap mengumpulkan informasi yang sebanyakbanyaknya. Hal yang bisa ditempuh adalah dengan pergi bersama teman. Namun, apabila dicermati, 25 \% dari wisatawan ini adalah pergi ke Batur Global Geopark sendirian. Ini jelas membuktikan bahwa wisatawan tersebut memiliki motivasi yang kuat untuk bisa berkunjung ke Batur Global Geopark. Di sisi lain memang karena Batur Global Geopark juga memiliki faktor penarik sebagai sebagai daya tarik wisata.

Orang yang diajak berkunjung ke suatu daerah tujuan wisata tidaklah terlalu memberikan keputusan apabila memang wisatawan tersebut telah memiliki motivasi yang jelas. Berbeda saat wisatawan menjadi repeater guest, mereka sudah mengetahui kondisi yang ada. Dalam hal ini Batur Global Geopark cukup mampu memberikan rasa aman sehingga mereka berani untuk datang dan tinggal sendirian. Namun, satu hal lain yang perlu dicermati adalah walaupun mereka datang sendirian, namun mereka telah berkunjung sebelumnya, dan pada kunjungan pertama tidak menutup kemungkinan mereka telah berkenalan dengan masyarakat lokal, sehingga apabila mereka datang berikutnya, sudah tidak seperti di daerah asing lagi. Seorang wisatawan mancanegara asal Australia yang bernama Erin Rice dikawasan Batur Global Geopark mengatakan "this place so beautiful and I feel happy when the see sunrises in the early morning"

Kutipan tersebut cukup singkat.Namun dari kutipan tersebut dapat terlihat bagaimana seorang wisatawan dapat mengatakan bahwa, dia begitu mengagumi keindahan Batur Global Geopark. Jelas pada perjalanan sebelumnya, wisatawan ini telah banyak melakukan aktivitas di kawasan Geopark.

\subsection{Berdasarkan Sumber Informasi tentang Batur Global Geopark}

Sebenarnya nama dari Batur Global Geopark belumlah populer di kalangan wisatawan, mereka berkunjung sebagaian besar karena pemandangan yang ada di Kintamani, yaitu gunung dan danau ataupun karena rute yang diatur 
oleh pihak travel agent. Wisatawan mengetahui informasi tentang Batur Global Geopark dari berbagai sumber. Sumber informasi yang paling banyak adalah lewat informasi dari travel agent yaitu sebesar 32 \%. Dari sumber lain, yaitu kunjungan sebelumnya sebesar 30\% sedangkan informasi tentang Batur Global Geopark dari internet mencapai 29\%, sumber iklan 8\%, dari informasi mulut ke mulut (words of mouth) sebesar 4\%. Made Neca seorang guide travel agent mengatakan:

Kami "menjual" Kintamani sudah sangat lama, jauh sebelum Kintamani menjadi geopark, sehingga kami selalu memiliki kunjungan ke Kintamani bila kami memiliki tamu yang datang ke Bali.

Sebenarnya hal ini bisa berdampak baik, karena apabila pihak travel sudah terus mau "menjual" produk Kintamani kepada wisatawannya, tentu Kintamani sebagai geopark akan lebih mudah untuk dikenal. Dengan orangorang selalu membicarakan sesuatu tempat, maka tempat tersebut akan lebih mudah masuk kedalam ingatan seseorang. Inilah proses pemasaran yang sangat efektif, yaitu produk tersebut harus dibicarakan. Selain itu, Batur Global Geopark perlu dikenal dengan cara mulut ke mulut agar Batur Global Geopark mampu meyakinkan semua wisatawan yang berkunjung. Keuntungan dari Batur Global Geopark bila dikenal dengan cara mulut ke mulut adalah Batur Global Geopark tidak perlu mengeluarkan biaya yang banyak untuk promosi. Namun yang akan menjadi permasalahan adalah ketika Batur Global Geopark tidak mampu memberikan pelayanan yang baik kepada wisatawan. Tentu apabila wisatawan komplain, mereka juga akan berbicara yang tidak baik tentang reputasi Batur Global Geopark, sehingga menjadi ancaman untuk pencitraan Batur Global Geopark dimata wisatawan.

\subsection{Berdasarkan Intensitas Kunjungan}

Hasil survei ini memperlihatkan wisatawan domestik dan mancanegara yang berkunjung ke Batur Global Geopark didominasi perjalanan satu kali mengunjungi Batur Global Geopark. Kunjunganyang berulang-ulang ke Batur Global Geopark perlu mendapat suatu perhatian yang lebih dalam, karena hanya 33\% dari 100 wisatawan. Tampaknya wisatawan mulai merasakan titik jenuh untuk berkunjung ke Batur Global Geopark, seperti penuturan seorang wisatawan Mancanegara George asal Canada mengatakan:

Kintamani was beautiful, but today what happen in Kintamani, there are too many restaurants along the road.

Kutipan ini mengandung makna ketidaksukaan wisatawan terhadap 
terlalu banyaknya restoran di sana, menghalangi pemandangan. Lebih jauh dari itu, pernyataan itu juga memiliki harapan untuk adanya pengelolaan yang lebih baik, sehingga tersedianya restoran tidak memperburuk kawasan Kintamani. George masih mencintai Kintamani dari dulu sebelum menjadi geopark sampai kini, akan tetapi George menyadari perubahan yang terjadi di Kintamani membuat Kintamani berbeda dengan yang dulu. Mulai terjadi kekeliruan dalam pembangunan di kawasan ini, sehingga terlihat Batur Global Geopark hanya berorientasi kepada keuntungan ekonomi tanpa mempertimbangkan aspek keberlanjutan pariwisatanya. Semakin banyak kecendrungan wisatawan yang khawatir tentang perubahan di Batur Global Geopark. Bisa jadi wisatawan kedepan tidak mau berkunjung kembali karena faktor Batur Global Geopark sendiri dan juga banyaknya muncul destinasi pariwisata yang mampu memenuhi kepuasan wisatawan. Perencanaan sangat diperlukan untuk mengantispasi dampak buruk dari jenuhnya wisatawan untuk berkunjung. Diperlukan untuk dilakukan inovasi dari aktivitas yang tersedia bagi wisatawan. Dengan adanya inovasi aktivitas wisatawan, akan bisa memotivasi wisatawan berkunjung ke Batur Global Geopark dengan pengembangan pariwisata alam dan kelestariannya. Inovasi produk membuat wisatawan selalu merasa penasaran sehingga tertarik akan berkunjung kembali dan akan memberikan manfaat keuntungan ekonomi terhadap masyarakat lokal. Hal ini sesuai dengan konsep keputusan wisatawan melakukan perjalanan (Wall, 1982; Shaw dan William, 1992);

\footnotetext{
"untuk menikmati produk yang dibeli, wisatawan harus mengunjungi daerah tujuan wisata secara langsung, berbeda dengan produk lain yang dikirim kepada pembeli. Produk pariwisata juga tidak dapat disimpan untuk dinikmati pada waktu yang berbeda”.
}

\subsection{Berdasarkan Tujuan Kunjungan}

Wisatawan yang berkunjung ke Batur Global Geopark mempunyai motivasi yang berbeda-beda. Sejumlah 54 \% wisatawan berkunjung ke Batur Global Geopark adalah untuk menikmati alam; 35\% dikarenakan bagian dari paket tour dan $11 \%$ adalah wisatawan bisnis. Dengan berlibur khususnya menikmati alam di Batur Global Geopark, wisatawan berharap akan mampu mendapatkan sesuatu yang baru didorong oleh fantasi motivasi (fantasy motivation). Fantasy motivation adalah dorongan untuk melepaskan dari rutinitas keseharian yang menjenuhkan dan yang memberikan kepuasan psikologis (Mcintosh, 1977 dan Murphy, 1985 dalam Pitana, 2005). Untuk motivasi wisatawan yang melakukan bisnis perlu mendapat perhatian, karena bisa menjadi peluang ataupun ancaman apabila wisatawan dibiarkan melakukan aktivitas tanpa dikontrol. Setelah mereka pernah melakukan perjalanan ke Batur Global Geopark, mereka akan mengetahui situasi Batur 
Global Geopark. Ini kemungkinan membuka peluang bisnis bagi mereka. Hal ini sejalan dengan konsep pariwisata menurut pandangan Suwantoro (1997), yang mengatakan:

dorongan kepergian wisatawan adalah karena berbagai kepentingan, baik karena kepentingan ekonomi, kebudayaan, politik, agama, kesehatan maupun kepentingan lain seperti seperti sekedar ingin tahu, menambah pengalaman atau pun untuk belajar.

Apabila dikaitkan dengan data yang diperoleh dari survei terdapat motivasi bisnis sesuai menurut pendapat dari Suwantoro. Pada intinya, kegiatan wisata adalah suatu perjalanan dari satu tempat ke tempat yang lain dengan motivasi tertentu. Dengan kata lain, motivasi wisatawan akan selalu berubah dari waktu ke waktu, karena pariwisata adalah suatu praktik sosial, sehingga pasti terjadi suatu interaksi sosial dan memberikan pemahaman baru bagi wisatawan. Tentunya hal tersebut harus diantispasi oleh masyarakat lokal di daerah tujuan wisata khususnya Kintamani yang telah memiliki brand geopark.

\subsection{Berdasarkan Lama Kunjungan}

Berdasarkan penelitian di Batur Global Geopark, untuk wisatawan memiliki waktu tinggal yang relatif tidak lama. Terhitung 55\% wisatawan domestik tinggal dalam jangka waktu kurang dari sehari; 20 \% berkunjung kurang 3-5 hari; 15\% 1-2 hari dan 10\% lebih dari seminggu. Lama kunjungan (length of visit) tentunya sangat berkaitan dengan aktivitas, uang, dan waktu yang dimilikinya untuk berlibur. Di sinilah peran pelaku pariwisata, agar mampu memberikan pilihan aktivitas wisata, sehingga wisatawan akan tinggal lebih lama lagi. Beberapa pilihan aktivitas tour yang banyak akan akan memunculkan rasa penasaran sebelum mereka mencoba aktivitas yang ditawarkan.

Lama kunjungan di suatu destinasi pariwisata ditentukan oleh parameter waktu, aktivitas yang disediakan oleh destinasi pariwisata. Berkaitan dengan Batur Global Geopark yang memiliki lama kunjungan yang relatif singkat disebabkan oleh beberapa factor: (a) Batur Global Geopark sebagai destinasi pariwisata belum mampu memberikan berbagai macam aktivitas yang dapat dijalankan oleh wisatawan selama mereka bekunjung; (b) Pemandangan yang indah yang belum didukung oleh keramah tamahan masyarakat di kawasan Batur Global Geopark; (c) Fasilitas wisata yang masih kurang. Lama kunjungan yang relatif singkat ini didukung oleh pernyaataan Made Pasek seorang pengelola guest house di kawasan Batur Global Geopark mengatakan;

Di sini wisatawan yang menginap paling hanya sehari, ini dikarena 
mereka melalukan hiking ke gunung Batur, dan setelahnya mereka kembali ke hotel awal di daerah Kuta atau Seminyak. Bahkan beberapa wisatawan tidak menginap jika mau melakukan hiking, mereka langsung diantar oleh sopir dan guide dari hotel mereka di kawasan Bali Selatan.

\section{Pengetahuan Wisatawan tentang Batur Global Geopark}

Pada umumnya wisatawan yang berkunjung ke Kintamani lebih banyak diorganisir oleh biro perjalanan wisata melalui paket tour yang dijual dan Kintamani menjadi tempat persinggahan hanya untuk makan siang sambil menikmati pemandangan danau dan Gunung Batur. Karena pertimbangan biaya, pihak travel agent akan mengarahkan perjalanan yang searah dari satu tujuan ke tujuan yang lainnya. Dari kasus ini, hanya sedikit wisatawan yang mengetahui bahwa Kintamani telah masuk menjadi anggota jaringan geopark dunia UNESCO.

Wisatawan melakukan interaksi yang sangat singkat serta pengetahuan tentang geopark dari wisatawan sangatlah minim. Hal ini terbukti dari aktivitasnya hanya makan siang, melihat pemadangan, berfoto dan akhirnya balik ke tempat menginap atau melanjutkan tournya ke tempat lain. Kalau pun ada, mereka biasanya hanya ingin melakukan pendakian (hiking) di gunung Batur, bukan karena Kintamani sudah menjadi geopark. Untuk itu, dari hasil penyebaran kuisioner tentang pengetahuan wisatawan baik domestik maupun mancangera terhadap geopark telah diperoleh sebagai berikut.

\subsection{Pengetahuan terhadap Keberadaan Batur Global Geopark}

Berdasarkan hasil penelitian ini sebanyak 95 orang wisatawan sebenarnya mengetahui keberadaan Batur Global Geopark. Dari 100 kuesioner yang disebar hanya 5 orang wisatawan yang belum mengetahui keberada Batur Global Geopark. Namun, dalam hal ini, pengetahuan dari adanya Batur Global Geopark masih bersifat sangat umum. Data berikutnya menyebutkan bahwa wisatawan yang berkunjung ke Kintamani tidak mengetahui daerah mana saja yang termasuk kawasan geopark di Kintamani.

\subsection{Pengetahuan Lingkup Kawasan Batur Global Geopark}

Sebanyak 87 orang wisatawan yang berkunjung ke Kintamani mengatakan Batur Global Geopark hanya yang terkait Gunung Batur. Sebanyak 10 wisatawan mangatakan geopark adalah seluruh Kecamatan Kintamani, 3 wisatawan menyatakan bahwa lingkup kawasan geopark adalah danau Batur. Bisa dipahami bahwa wisatawan mengenal geopark dikarenakan nama yang sama dengan nama danau dan nama gunungnya. Namun, pada kenyataannya wisatawan belum mengerti apa tujuan geopark. 


\subsection{Pengetahuan Tujuan Pengembangan Batur Global Geopark}

Dari hasil survey tentang pengetahuan wisatawan tentang tujuan pengembangan geopark, sebanyak 89 persen wisatawan menjawab sebagai konservasi kawasan; 6 persen sebagai penghasilan daerah; dan 5 persen lainnya dikatakan untuk pengembangan aktivitas kepariwisataan.

\subsection{Pengetahuan Fasilitas Pendukung Batur Global Geopark}

Dilihat dari pengetahuan wisatawan dari fasilitas pendukung geopark, 74 persen wisatawan mengetahuinya karena terlihat pada ucapan selamat datang kepada wisatawan. Enam belas persen wisatawan menyatakan diketahui geopark karena adanya museum kaldera gunung api Batur. Melihat hal ini, pemahaman wisatawan terhadap geopark perlu disosialisasikan lebih lanjut, agar wisatawan juga mengerti apayang harus dilakukan jika berkunjung ke Kintamani. Tourist Information Centre juga sangat minim dan terkesan kurang diperhatikan oleh pihak pengelola. Wisatawan kesulitan memperoleh informasi tentang geopark. Permasalahan lain yang terjadi terkait Batur Global Geopark adalah banyaknya sampah di sekitar kawasan pariwisata Kintamani. Kesan kumuh juga dirasakan di area penelokan yang menjadi tempat melihat pemandangan dari atas karena tempat ini terdapat pasar tradisonal yang tidak tertata dengan baik.

Ketika memahami kegiatan pariwisata seharusnya tidak hanya melihat ketika pariwisata berlangsung. Melainkan perlu melihat bahwa sebenarnya kegiatan pariwisata menyangkut dimensi sebelum kegiatan, selama kegiatan dan sesudah kegiatan. Dimensi itu memang di luar jangkauan dari industri pariwisata, namun perencana pariwisata masih dapat membangun sebuah kebijakan destinasi yang didesain untuk mendapatkan hasil yang diharapkan. Wisatawan mengunjungi suatu daerah tujuan wisata antara lain didorong oleh keinginan untuk mengenal, mengetahui, atau mempelajari daerah dan kebudayaan masyarakat lokal. Selama berada di daerah tujuan wisata, wisatawan pasti berinterkasi dengan masyarakat lokal, bukannya dengan mereka yang secara langsung melayani kebutuhan wisatawan (karyawan hotel, pemandu wisata, karyawan restoran, dan sebagainya), melainkan juga dengan masyarakat secara luas.

Interaksi dengan masyarakat luas ini semakin intensif kalau jenis pariwisata yang dikembangkan adalah pariwisata budaya, karena kebudayaan melekat pada kehidupan masyarakat sehari-hari. Pada jenis pariwisata lain, seperti marine tourism atau adventure tourism, interaksi dengan masyarakat lokal mungkin kurang intensif, karena objek yang ditemui adalah alam/benda mati. Untuk itu, dalam memahami respon wisatawan baik domestik dan mancanegara dalam pengembangan Batur Global Geopark, wisatawan diminta untuk memberikan tanggapan yang terlihat dari sikap, persepsi dan partisipasinya (Foto 3). 


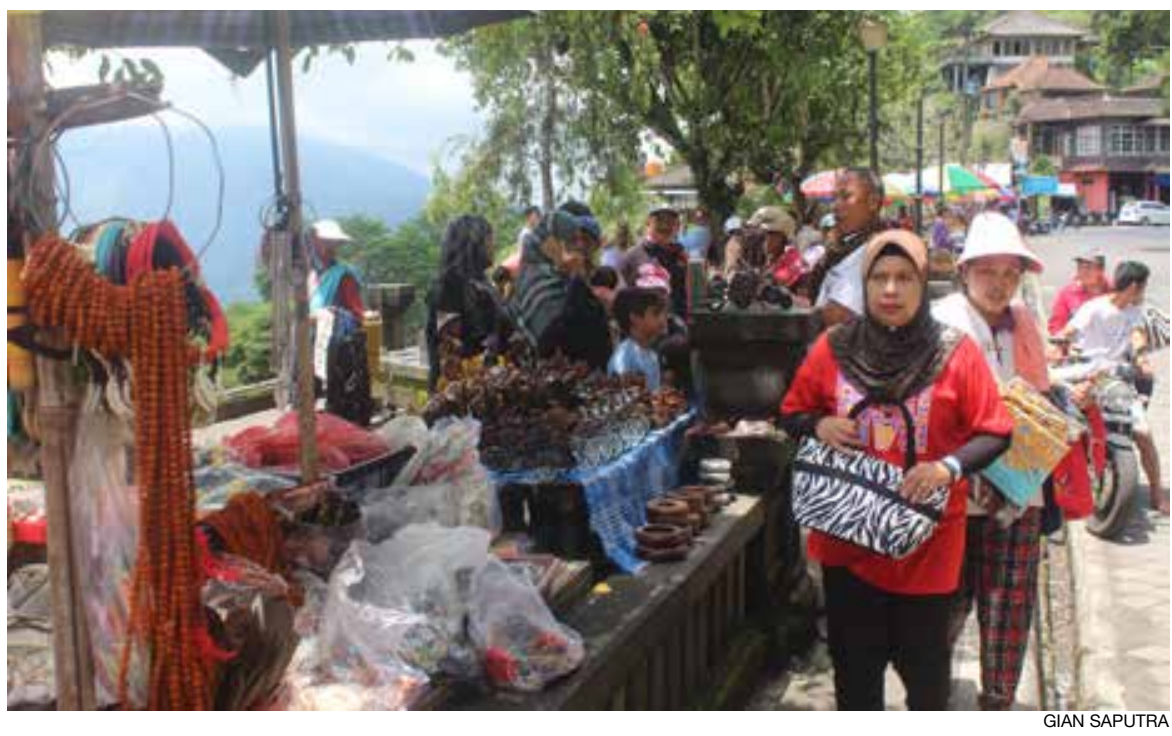

Foto 3. Wisatawan dan penjual souvenir di kawasan Batur Global Geopark.

\section{Sikap Wisatawan Domestik dan Mancanegara}

Berdasarkan survei ini, wisatawan yang berkunjung ke Kintamani memiliki sikap negatif. Hal ini dikarenakan wisatawan belum mengetahui secara utuh konsep dari pengembangan geopark. Setelah adanya sedikit penjelasan tentang apa itu geopark, para wisatawan sangat mendukung pengembangan geopark di Kintamani. Ini terbukti dari penilaian wisatawan terhadap pentingnya pengembangan geopark di Kintamani yang mendapat nilai sangat positif. Akan tetapi, hal ini sangat berlawanan dengan kondisi yang ada saat ini di mana penilaian wisatawan terhadap pengetahuan keberadaan geopark di Kintamani mendapat nilai sangat negatif. Ini berarti, para pengelola pariwisata di Kintamani perlu untuk lebih memperkenalkan konsep geopark kepada para wisatawan.

\subsection{Persepsi Wisatawan Domestik dan Mancanegara}

Dilihat dari persepsi wisatawan terhadap pengembangan Batur Global Geopark terdapat tiga indikator yang menjadi penilaian. Rata-rata dalam pemahaman wisatawan tentang geopark cukup positif. Penilaian wisatawan tentang pentingnya pengembangan pariwisata berbasis masyarakat sangat positif. Penilaian wisatawan tentang konsep dasar geopark negatif. Hal ini disebabkan oleh kurangnya pengetahuan mereka tentang geopark. Penilaian wisatawan tentang kawasan geopark cukup positif. Ini berarti wisatawan menginginkan adanya penyebaran pengembangan pariwisata di Kintamani untuk memperluas jangkauan dan keberagaman aktivitas bagi wisatawan yang berkunjung. 


\subsection{Partisipasi Wisatawan Domestik dan Mancanegara}

Partisipasi wisatawan terhadap pengembangan Batur Global Geopark, berdasarkan rata-rata nilai partisipasi wisatawan adalah cukup negatif. Indikator partisipasi wisatawan untuk membayar aktivitas konservasi hanya mendapat nilai satu artinya sangatlah negatif. Indikator wisatawan membayar geopark hanya mendapat nilai dua, sedangkan indikator partisipasi wisatawan untuk mencari informasi mengenai geopark mendapat nilai positif. Berdasarkan data tersebut, wisatawan memang belum mengetahui apa sebenarnya geopark. Hal ini menyebabkan partisipasi wisatawan juga menjadi pasif, berpengaruh terhadap sikap wisatawan yang negatif dan persepsi wisatawan yang kurang positif terhadap pengembangan geopark.

\section{Penutup}

Ditetapkannya Batur Global Geopark masih belum dipahami oleh wisatawan yang berkunjung. Secara umum wisatawan tidak mengerti dengan apa yang dimaksud dari pengembangan geopark. Wisatawan yang telah melakukan beberapa kali kunjungan tidak melihat adanya perbedaan dari aktivitas yang dijalani berkaitan dengan keberadaan geopark, sehingga tujuan pengembangan geopark seperti untuk konservasi, edukasi dan peningkatan ekonomi masyarakat lokal belum tercapai. Apabila wisatawan sebagai pembeli produk pariwisata tidak mengetahui produk yang ditawarkan oleh Batur Global Geopark, maka tujuan tersebut hanya sebatas wacana tanpa adanya keseriusan untuk membangun Kintamani.

Kenyataan ini bisa dibuktikan dari sikap wisatawan memberikan penilaian negatif. Pada respon persepsi, penilaian wisatawan adalah negatif karena mereka belum mengerti apa itu geopark. Dari sisi partisipasi, wisatawan memberikan penilaian negatif artinya, wisatawan belum mau berpartisipasi dalam pengembangan geopark. Hal ini disebabkan oleh pemahaman wisatawan tentang geopark sangatlah rendah. Oleh karena itu, diperlukan pengenalan yang lebih mendalam oleh wisatawan agar Batur Global Geopark dapat menjadi daya tarik bagi wisatawan berkunjung ke Kintamani. Salah satu upaya yang dapat dilakukan adalah menciptakan suatu rute perjalanan baru bagi wisatawan yang khusus mencakup Batur Global Geopark.

\section{Ucapan Terima Kasih}

Terima kasih yang sebesar-besarnya penulis sampaikan kepada semua pihak yang telah membantu penulisan jurnal ini tepat pada waktunya. Terkhusus penulis sampaikan ucapan terima kasih kepada Prof. Dr. I Nyoman Darma Putra, M. Litt. dan Dr. Ir. Syamsul Alam Paturusi, MSP. selaku Ketua dan Sekretaris Program Studi Kajian Pariwisata Universitas Udayana. Kepada teman-teman Magister Kajian Pariwisata angkatan 2013. Terima kasih juga kepada Sekretariat Program Studi Magister Pariwisata Universitas Udayana 
atas segala fasilitas yang mendukung penyelesaian jurnal ini.

\section{Daftar Pustaka}

Batur Global Geopark. 2014. Pemerintah Kabupaten Bangli. Dinas Kebudayaan dan Pariwisata. www.baturglobalgeopark.org

Butler, R.W. 2006. The Concept of ATourist Area Life Cycle of Evolution: Implications for Management of Resources in The Tourism Area Life Cycle. Volume 1 Applications and Modifications. Clevedon: Channelview Publications.

Dinas Pariwisata Provinsi Bali Tahun. 2015. Data Kunjungan Wisatawan ke Pulau Bali.

Edi Setyawan, I Wayan, dkk. 2014. Partisipasi Masyarakat Dalam Pengelolaan Kawasan Wisata Geopark Batur di Kecamatan Kintamani Kabupaten Bangli. Jurnal Pendidikan Geografi Vol. 5.

Eilers, J. F. 1995. Berkomunikasi antar Budaya. Jakarta: Nusa Indah.

Farsani, et al. 2012. Geotourism and Geoparks as Gateways to Socio-cultural Sustainability in Qeshm Rural Areas, Iran. Asia Pacific Journal of Tourism. Research, 17:1,30-48, Diakses Sabtu o6 Juli 2014

Guidelines and Criteria for National Geoparks seeking UNESCO's assistance to join the Global Geoparks Network (GGN).April, 2010.

Moleong, Lexy J. 2012. Metode Penelitian Kualitatif. Bandung: Rosda.

Pitana, I Gde. 2005. Sosiologi Pariwisata, Kajian Sosiologis Terhadap Struktur, Sistem, dan Dampak-Dampak Pariwisata. Yogyakarta: Andi Offset.

Putra, IND. 2014. "Bali, Between Cultural and Marine Tourism”, Jurnal Kajian Bali, Volume 04, Nomor 01, April 2014, pp. 15-30.

Setyadi, Dhika Anindhita. 2012. Studi Komparasi Pengelolaan Geopark di Dunia untuk

Pengembangan Pengelolaan Kawasan Cagar Alam Geologi Karangsambung”. Jurnal Pembangunan Wilayah dan Kota, Volume 8 (4):392-4 diunduh 02 Desember 2012

Spillane, James, J.1993. Ekonomi Pariwisata. Yogyakarta. Kanisius

Swastha, Basu \& T. Hani Handoko. 1997. Manajemen Pemasaran, Analisa dan Perilaku Konsumen. Yogyakarta: BPFE.

Undang-Undang No.10 Tahun 2009 tentang Kepariwisataan.

UNWTO, 2011. http;//www.unwto.org diakses pada Selasa o8 Desember 2014.

\section{Profil Penulis}

I Gede Gian Saputra, S.Par. menyelesaikan pendidikan Program Magister Kajian Pariwisata di Universitas Udayana tahun 2015. Untuk jenjang S-1, dia menyelesaikan Program Studi Destinasi Pariwisata di Fakultas Pariwisata Universitas Udayana. Ketertarikannya dalam bidang pariwisata mulai dilakoninya dengan bekerja di salah satu industri perjalanan wisata di Bali. Minat penelitiannya meliputi topik tentang perilaku wisatawan, perencanaan, dan pemasaran pariwisata. 